245

Received: October 31, 2017

Accepted: December 13, 2017
Macedonian Journal of Animal Science, Vol. 7, No. 1-2, pp. 123-127 (2017)

ISSN $1857-6907$

e-ISSN $1857-7709$

UDC: 636.92 .087 .8

Original scientific paper

\title{
EFFECT OF PROBIOOTIC “ZOOVIT” ON PRODUCTIVITY OF RABBITS
}

\author{
Nedka Dimova ${ }^{1}$, Staika Laleva ${ }^{1}$, Petia Slavova ${ }^{1}$, Yovka Popova ${ }^{1}$, \\ Milena Mihaylova ${ }^{1}$, Nikola Pacinovski ${ }^{2}$ \\ ${ }^{\text {I} A g r i c u l t u r a l ~ I n s t i t u t e, ~ S t a r a ~ Z a g o r a, ~ B u l g a r i a ~}$ \\ ${ }^{2}$ Institute of Animal Science, Ss Cyril and Methodius University in Skopje, \\ Blvd. Ilinden 92A, 1000 Skopje, Republic of Macedonia \\ ned_dimova@abv.bg
}

\begin{abstract}
The experiments included 50 does and 36 weaned rabbits of the White New Zealand breed. The animals were divided into two groups - experimental and control. The exeprimental group was supplemented with probiotic "ZOOVIT". The addition of "ZOOVIT" probiotic increases the fertility rate, which is $85,71 \%$ in the experimental and $66,66 \%$ in the control group. The number of the live born rabbits is also higher in the experimental animals. In the experimental group is recorded a $10.8 \%$ lower mortality rate before weaning and a $10.9 \%$ higher average daily growth rate than in the control one. In rabbits for fattening, the experimental group has a $11.11 \%$ lower mortality rate. The additive used reliably increases live weight in the test group. Further studies are needed to establish the optimal doses of "ZOOVIT" in rabbit does, growing rabbits and rabbits for fattening.
\end{abstract}

Key words: probiotic; rabbit does; growing rabbits; fattening rabbits; live weight

\section{ВЛИЈАНИЕ НА ПРОБИОТИКОТ „ЗООВИТ“ ВРЗ ПРОДУКТИВНОСТА НА ЗАЈАЦИТЕ}

\begin{abstract}
Експериментите опфаќаат 50 женки и 36 зајаци во растеж од расата White New Zealand. Животните беа поделени во две групи - експериментална и контролна. Експрименталната група беше со додаден пробиотик „ЗООВИТ“. Додавањето на пробиотикот „ЗООВИТ“ ја зголемува стапката на фертилитет, која изнесува 85,71\% во експерименталната и $66,66 \%$ во контролната група. Бројот на живородени зајаци е исто така поголем кај експерименталните животни. Во експерименталната група е забележана стапка на смртност пред одбивање пониска за 10,8\% и за 10,9\% повисока просечна дневна стапка на прираст во однос на контролната група. Кај зајаците за гоење експерименталната група има пониска стапка на смртност за 11,11\%. Адитивот кој се користеше со сигурност ја зголемуваше живата маса во тестираната група. Потребни се понатамошни испитувања за да се утврдат оптимални дози на „ЗООВИТ“ кај женките, зајаците во ратеж и зајаците за гоење.
\end{abstract}

Клучни зборови: пробиотик; зајаци женки; зајаци во растеж; зајаци за гоење; жива маса

\section{INTRODUCTION}

Rabbit meat is interested with its dietary and nutritional characteristics and the biosafety for the consumer. By intensifying production systems and simultaneously exposing various stress factors, antibiotics at subtherapeutic levels have been widely introduced in rabbits as growth promoters for a long time.

Their proven risk has led to banning the use of antibiotics in feeding rabbits and increased interest in the use of alternative natural products that will allow to maintain high fertility and reduce disease and mortality on farms.
Probiotics are defined as 'a live microbial feed supplement which beneficially affects the host animal by improving its intestinal balance' (Fuller, 1989). Due to the unique physiology of digestive tract, rabbits usually show a fragile balance in their gut function and frequently suffer from post-weaning alimentary disturbances and probiotics may contribute to improve their health status (Trocino et al., 2005; Kritas et al. 2008, according to Bhatt et al., 2017).

The model of action of probiotics has not yet been well studied. In contrast to antibiotics, probiotics have no intention of destroying pathogenic bac- 
teria but have a barrier effect against pathogens, prevent their development and colonization and ensure optimal feed utilization (Maertens et al., 1994). They improve digestion through the production of enzymes and vitamins such as these and thus enhance non-specific immunological protection (Kustos et al., 2004).

According to Nicodemus et al. (2004), the reduction of pathogenic microorganisms in the intestine is likely due to the direct action of the probiotics or the indirect stimulation of the useful bacteria population.

Falcao et al. (2007) reviewed results of probiotics in rabbits reporting a positive effect on average daily gain (ADG), feed conversion ratio and a lower mortality in most of the experiments (Bhatt et al. 2017).

Probiotics as a food supplement have great potential to improve the balance of intestinal microorganisms.

Products containing mainly bacteria of the genera Lactobacilli, Bifidobacteria, Lactococcus, Bacillus and Pediococcus, and yeasts (Saccharomyces strains) are used in rabbits.

The object of the present study is to determine the effect of the probiotic product "ZOOVIT" on conception rate and fertility, of does as well as the weight development and health status of suckling rabbits and rabbits for fattening.

\section{MATERIAL AND METHODS}

\section{Pregnant, lactating and suckling rabbits}

The experience was conducted in the Experimental farm of the Agricultural Institute, Stara Zagora, with two groups of 26 and 24 does from the White New Zealand breed. During the experiment, the following indicators were monitored: fertility $(\%)$, live born (\%), dead born (\%), mean breeds of 1 female (live + stillborn), weaned rabbits of 1 bunch and health.

\section{Rabbits for fattening}

Two groups were formed - experimental and control, with 18 rabbits in each, equalized by sex, live weight and age. During the experiment, the health status of the rabbits was checked daily in terms of vitality, digestive disorders and mortality. The weighing of the animals was monitored by individual weighing in 14 days. The experiment lasted 87 days.
The following parameters were monitored: weight at weaning (g), live weight over 15 days, average daily gain (g), live weight at 12 weeks.

The experimental results were analyzed using one-way ANOVA, covariance and correlations tests, and significant differences between groups were determined with the Duncan's multiple range test. Differences were considered significant at $\mathrm{P} \leq$ 0.05 . The Statistica for WindowsTM software package version 8.0 (STATSOFT INC., 2007) was used for the data evaluation.

\section{RESULTS AND DISCUSSION}

\section{Pregnant, lactating does and suckling rabbits}

The composition and nutritional value of the feed was the same both for the control and experimental rabbits (Table 1), the difference consisted only in the addition of $0.5 \%$ probiotic in the test group.

\begin{tabular}{lc} 
Tab $1 \mathrm{e} 1$ \\
$\begin{array}{c}\text { Ingredients and nutritional value of granulated } \\
\text { feed for pregnant and rabbit does with }\end{array}$ \\
\multicolumn{1}{c}{ and without added } \\
probiotic
\end{tabular}


The results showed that fertility was $19.05 \%$ higher in the experimental group (Table 2).

Table 2

\section{Effect of a $0.5 \%$ probiotic on conception rate, fertility and the development of rabbits during the lactating period}

\begin{tabular}{|c|c|c|}
\hline Items & $\begin{array}{l}\text { Control } \\
\text { group }\end{array}$ & $\begin{array}{l}\text { Experimental } \\
\text { group }\end{array}$ \\
\hline Number of rabbit does & 24 & 28 \\
\hline Fertility, \% & 66.66 & 85.71 \\
\hline Born live rabbits, $\%$ & $142 / 100$ & $200 / 140.84$ \\
\hline Born dead, \% & 3 & 11 \\
\hline $\begin{array}{l}\text { Mean number of born rabbits } \\
\text { per mother (live }+ \text { born dead) }\end{array}$ & 9.06 & 8.79 \\
\hline Weaned rabbits, $\%$ & 66.20 & 77.00 \\
\hline $\begin{array}{l}\text { Average number weaned rabbits } \\
\text { from } 1 \text { litter }\end{array}$ & 5.87 & 6.42 \\
\hline Live weight at weaning, $g$ & 741.30 & 777.01 \\
\hline Mortality before weaning, $\%$ & 33.8 & 23.0 \\
\hline
\end{tabular}

The average number of born rabbits per doe was $2.98 \%$ higher in the control group. The average number of weaned rabbits in the control and experimental groups was 5.87 and 6.42 respectively. On average, one rabbit is weaned by $9.34 \%$ more rabbits than the experimental group.

Similar results were reported by Abdel-Samee (1993) in experiments with probiotic "Lacto-Sacc", where the number of liveborn rabbits increased by $16 \%$ and the number of the weaned by $11 \%$.

Weaned rabbits from the test group had 35.41 $\mathrm{g}$ higher live weight than the ones from the control group. The probiotic used reduced the mortality by $10.8 \%$.

Lower mortality in experimental group is probably due to increased IgA secretion (immuneglobulin A) and prevention of E. coli enteritis due to the action of Lactobacilli bacteria found by Ogawa et al. (2001).

\section{Rabbits for fattening}

The composition and nutritional value of the feed was the same for control and experimental rabbits (Table 3), the difference consisted only in the addition of $0.5 \%$ probiotic.
Table 3

Composition $(\mathrm{g} / \mathrm{kg})$ and nutritive value of basal diet feed for fattening rabbits with and without a probiotic additive

\begin{tabular}{lc}
\hline \hline Ingredients & $\%$ \\
\hline Barley & 42.150 \\
Wheat & 10.000 \\
Lucerne hay & 25.000 \\
Sunflower meal & 20.000 \\
Dicalcium phosphate & 0.400 \\
Limestone & 0.800 \\
Salt & 0.500 \\
Micofix & 0.200 \\
Biotronic & 0.250 \\
Lysine -98\% & 0.200 \\
Premix Rabbits & 0.500 \\
Probiotic & $-/+$ \\
Total & $\mathbf{1 0 0}$ \\
Dry matter & 89.100 \\
Crude protein & 17.307 \\
Crude fiber & 12.170 \\
Ca & 1.183 \\
P & 0.599 \\
Lysine & 0.853 \\
Methionine + cystine & 0.690 \\
ME, kcal/kg & 2076.255 \\
\hline \hline
\end{tabular}

Table 4 provides data on weight development, feed consumption and mortality rate in growing rabbits with or without a probiotic in the ration. The average daily gain for the study period was $24.50 \mathrm{~g}$ in the control group to $26.80 \mathrm{~g}$ in the test group. Rabbits supplemented with probiotics had a $9.39 \%$ higher growth rate. It was found that the differences in growth rate were statistically reliable at $\mathrm{P}<0.05$.

Similar results were obtained by Abdel-Samee (1993), in White New-Zealand rabbits, where the average daily gain was $24.3 \mathrm{~g}$ and $26.3 \mathrm{~g}$ in the control and trial groups, and the probiotic increased the growth by $11 \%$.

The average daily gain in our study was lower than that observed in earlier studies by Surdzijska et al. (2004), where the average daily growth in the groups was in the range of $32.5-37.2 \mathrm{~g}$. 
Regarding the utilization of the feed, it can be seen that the feed rate per $1 \mathrm{~kg}$ increase in weight was higher in the control group compared to the test one by $8.59 \%$.

During the experiment, animals were monitored for possible gastrointestinal disorders caused by pathogenic microorganisms.

At Table 4 it can be seen that the established mortality rate during the test period in numbers and percentage by groups was $27.78 \%$ for the control one and 16.67 for the experimental, respectively. The addition of probiotic in the ration significantly reduces the mortality in the test animals and reliably increases the live weight at the 6th control weighing $(\mathrm{p}<0.001)$ (Table 5).

Despite the lower cost of feed in the trial group, this is a trend, because the differences can not be statistically processed due to the group feeding of the rabbits. The results obtained are higher than those of Kritas et al. (2008) where the rabbits has $4.7 \%$ higher live weight and $6.7 \%$ higher average daily gain.

Addition of a probiotic in the diet significantly reduced the mortality in the test animals and significantly increased the live weight at the 5 th $(\mathrm{p}<0.05)$ and the 6 th $(\mathrm{p}<0.01)$ control weighing (Table 5).
Table 4

Growth, feed consumption, and mortality of growing rabbits with and without a probiotic in the ration

\begin{tabular}{lcc}
\hline \hline Items & $\begin{array}{c}\text { Control } \\
\text { group }\end{array}$ & $\begin{array}{c}\text { Experimental } \\
\text { group }\end{array}$ \\
\hline $\begin{array}{l}\text { Number of animals in the } \\
\text { group }\end{array}$ & 18 & 18 \\
$\begin{array}{l}\text { Age at start of experience, } \\
\text { days }\end{array}$ & 36 & 36 \\
Experimental period, days & 84 & 84 \\
$\begin{array}{l}\text { Initial live weight, kg } \\
\text { Final live weight, kg }\end{array}$ & $693.16 \pm 12.79$ & $696.67 \pm 31.29$ \\
Average daily weight gain, g & $24.50 \pm 0.53 *$ & $26.80 \pm 0.60 *$ \\
in \% & 100 & 109.39 \\
Average feed intake, g/day & 142.66 & 142.50 \\
$\begin{array}{l}\text { Feed utilization, in \% } \\
\text { relative to the control group }\end{array}$ & 100 & 91.41 \\
\begin{tabular}{l} 
Mortality, \% \\
\hline \hline
\end{tabular} & 27.78 & 16.67 \\
\hline - significance $\mathrm{P}<0,05$ & & \\
\hline
\end{tabular}

* - significance $\mathrm{P}<0,05$

Table 5

Weight development of fattening rabbits during the experimental period

\begin{tabular}{|c|c|c|c|c|c|c|c|}
\hline Items & $\begin{array}{l}\text { Live weight in } \\
\text { the beginning, } g \\
\quad \mathrm{x} \pm \mathrm{Sx}\end{array}$ & $\begin{array}{c}\text { I } \\
\text { weighing } \\
x \pm S x\end{array}$ & $\begin{array}{c}\text { II } \\
\text { weighing } \\
x \pm S x\end{array}$ & $\begin{array}{c}\text { III } \\
\text { weighing } \\
\mathrm{x} \pm \mathrm{Sx}\end{array}$ & $\begin{array}{c}\text { IV } \\
\text { weighing } \\
\mathrm{x} \pm \mathrm{Sx}\end{array}$ & $\begin{array}{c}\mathrm{V} \\
\text { weighing } \\
\mathrm{x} \pm \mathrm{Sx}\end{array}$ & $\begin{array}{c}\text { VI } \\
\text { weighing } \\
\mathrm{x} \pm \mathrm{Sx}\end{array}$ \\
\hline \multicolumn{8}{|c|}{ Experimental group } \\
\hline $\begin{array}{l}\text { Average daily } \\
\text { gain, } g\end{array}$ & - & $24.92 \pm 3.87$ & $43.99 \pm 3.86$ & $26.19 \pm 2.46$ & $26.50 \pm 8.74$ & $18.84 \pm 1.48$ & $19.17 \pm 2.51$ \\
\hline Live weight, $g$ & $691.11 \pm 34.09$ & $1040.00 \pm 44.30$ & $1699.78 \pm 41.46$ & $2261.47 \pm 58.61$ & $2454.33 \pm 39.11$ & $2737.00 \pm 37.24^{\mathfrak{c}}$ & $3005.33 \pm 42.39^{\mathbf{b}}$ \\
\hline \multicolumn{8}{|c|}{ Control group } \\
\hline $\begin{array}{l}\text { Average daily } \\
\text { gain, } \mathrm{g}\end{array}$ & - & $22.22 \pm 63.79$ & $47.24 \pm 7.49$ & $22.31 \pm 5.53$ & $23.41 \pm 2.23$ & $16.00 \pm 1.63$ & $15.19 \pm 3.50$ \\
\hline Live weight, $\mathrm{g}$ & $693.33 \pm 12.79$ & $1004.44 \pm 73.33$ & $1702.86 \pm 63.79$ & $2171.43 \pm 75.77$ & $2347.69 \pm 74.40$ & $2587.69 \pm 66.17^{\mathfrak{c}}$ & $2800.39 \pm 58.12^{\mathbf{b}}$ \\
\hline
\end{tabular}

$\mathbf{b}-$ significance at $\mathrm{p}<0.01 ; \mathbf{c}-$ significance at $\mathrm{p}<0.05$

Probiotics containing lactic acid bacteria have a positive effect on health, feed costs and average daily gain. Kustos et al. (2004) found that the probiotic BioPlus 2B significantly reduced mortality by $17 \%$ and tended to decrease feed consumption and increased the average daily gain in rabbits for fattening.
The efficacy of a commercial probiotics (BioPlus 2B(i); B. licheniformis, B. subtilis) on weekly growth performance of rabbits found similar feed intake and BW gain with non-significant difference in feed conversion rate (Kustos et al., 2004; Matusevičius et al. 2006). It has been shown that feeding of probiotics may have a growth promoting 
activity by competing with harmful gut flora and stimulating the immune system (Kritas et al., 2008). A higher growth rate in probiotic supplemented rabbits may also suggest a better health status, more importantly the gastrointestinal health of the rabbits (Falco-e-Cunha et al., 2007; Kritas et al.2008, ).

\section{CONCLUSIONS}

The following conclusions can be drawn, based on the results of the study: probiotic "ZOOVIT" has a positive influence on the conception and fertility rate of does, on the health status of the suckling rabbits and reduces the mortality before weaning by $10.8 \%$. The rabbits from the test group have a $10.9 \%$ higher average daily gain.

In rabbits for fattening, the experimental group has a $11.11 \%$ lower mortality rate. The additive used reliably increases the live weight in the test group.

Further studies are needed to establish the optimal doses of "ZOOVIT" in pregnant does, growing rabbits and rabbits for fattening.

\section{REFERENCES}

[1] Abdel-Samee, A.: Using some antibiotics and probiotics for alleviating heat stress on growing and doe rabbits. World Rabbit Sci., 3 (3), 107-111 (1995).

[2] Bhatt, R. S., Agrawal, A. R., Sahoo, A.: Effect of probiotic supplementation on growth performance, nutrient utilization and carcass characteristics of growing Chinchilla rabbits, Journal of Applied Animal Research, 45, 1, 304-309 (2017). DOI:10.1080/09712119.2016.1174126

[3] Fuller, R.: Probiotics in man and animals. J Appl Bacteriol. 66, 365-368. (1989). DOI: 10.1111/j.1365-2672.1989.tb05105.

[4] Falcao-E-Cunha L., Castro-Solla L., Maertens L., Marounek L., Pinheiro V., Freire J., Mourao, J. L.: Alternatives to antibiotic growth promoters in rabbit feeding: a review. World Rabbit Sci. 15, 127-140 (2007).

[5] Kritas, S. K., Petridou, E. I., Fortomaris, P., Tzika, E., Arsenos G., Koptopoulos, G.: The Effect of Probiotics on Microbiology, Health and Performance of Fattening Rabbits Asian-Aust. J. Anim. Sci. Vol. 21, No. 9, 1312-1317 (2008).

[6] Kustos, K., Kovác, D., Gódor-Surmann, K., Eiben, C. S.: Effect of probiotic bioplus $2 \mathrm{~B} \AA$ on performance of growing rabbit. In: Proceedings: 8th World Rabbit Congress, 7 10 September, 2004. Puebla, Mexico. 874-879, 2004.

[7] Maertens, L., Van Renterghem, R., De Groote, G.: Effects of dietary inclusion of Paciflor ${ }^{\circledR}$ (Bacillus CIP 5832) on the milk composition and performance of does and on caecal and growth parameters of their weanlings. World Rabbit Sci., 2 (2), 67-73 (1994).

[8] Matusevičius, P., Ašmenskaitè, L., Žilinskienė, A., Gugolek, A., Lorek, M. O., Hartman, A.: Effect of probiotic Bioplus $2 \mathrm{~B} \circledast$ on performance of growing rabbit. Veterinariairzootechnik. 56, 54-59 (2006).

[9] Nicodemus, N., Carabaño, R., García, J., De Blas, J. C.: Performance response of doe rabbit to Toyocerin ${ }^{\circledR}$ (Bacillus cereus var. Toyoi) supplementation. World Rabbit Sci., 12, 109-118 (2004).

[10] Ogawa, M., Shimizu, K., Nomoto, K., Takahashi, M., Watanuki, M., Tanaka, R., Tanaka, T., Hamabata, T., Yamasaki, S., Takeda, Y.: Protective effect of Lactobacillus casei strain Shirota on Shiga toxin- producing Escherichia coli $\mathrm{O} 157: \mathrm{H} 7$ infection in infant rabbits. Infect. Immun., 69, 1101-1108 (2001).

[11] Surgiyska, S., Ganev, G., Slavova, P., Stoilov, I., Vladimirova, L., Tankov, D.: Effect of additive of probiotic Lactina to combined feed on productivity of rabbits. Journal of Animal Sciences. 2, 13-16 (2004).

[12] Timmerman, H. M., Mulder, L., Everts, H., Van Espen, D. C., Van Der Wal, E., Klaassen, G., Rouwers, S. M., Hartemink, R., Rombouts, F. M., Beynen, A. C.: Health and growth of veal calves fed milk replacers with or without probiotics. J. Dairy Sci. 88 (6) 2154-2165(2005).

[13] Trocino, A., Xiccato, G., Carraro, L., Jimenez, G.: Effect of diet supplementation with Toyocerin (Bacillus cereus var toyoi) on performance and health of growing rabbits. World Rabbit Sci. 13, 15-26 (2005). 
